\title{
Precarização e resistência docente: Memórias de greves e crise de mobilização na Secretaria Estadual de Educação de São Paulo
}

\author{
Precarization and teacher resistance: Memories of strikes and \\ mobilization crisis in the SEE-SP
}

Mariana Esteves de Oliveira*

\begin{abstract}
Resumo: Neste artigo, divulgamos parte da pesquisa de doutorado acerca do processo de precarização do trabalho docente na SEE-SP, sob a luz da História Social do Trabalho. Aqui, especificamente, apresentaremos a relação entre resistência docente e o processo de precarização, observada por meio da revisão bibliográfica e, principalmente, de memórias de professores aposentados e dos sentidos atribuídos pelos professores em atividades, desvelando o cenário de mobilização da categoria na sua dimensão de crise, reflexão e recriação da resistência. Conclui-se, nele, que a crise de mobilização docente é mais um elemento a ser compreendido como instrumento da precarização do trabalho de professores, na medida em que está engendrado para a fragmentação da categoria e, em tal perspectiva, se realiza.
\end{abstract}

Palavras-Chave: Precarização do trabalho docente; resistência; memórias de greves, crise de mobilização.

\begin{abstract}
In this article, we disclose part of the doctoral research on the casualization process of teaching in SEE-SP, based on Social Work History. Here, specifically, we present the relationship between teacher resistance and the casualization process observed by literature review and mainly of retired teachers memories and meanings attributed by teachers in activities, unveiling the category mobilization scenario in size of crisis, reflection and recreation of resistance. It is concluded that the crisis of teacher mobilization is another element to be understood as an instrument of the precariousness of teachers' work, since it is engendered for the fragmentation of the category and, in this perspective, it is realized.
\end{abstract}

Keywords: Precarious teaching work; resistance; strikes memories, mobilization crisis.

Recibido: 7 enero 2017

Aceptado: 22 marzo 2017 


\section{Introdução: Aportes e debates da pesquisa sobre resistência docente}

Em nossa pesquisa de doutorado, defendida no Programa de Pós Graduação em História da UFGD sob o título de "Professor, você trabalha ou só dá aula?", propomos uma reflexão acerca das formas pelas quais os professores da Secretaria Estadual de Educação de São Paulo - SEE-SP experimentam o processo de precarização do trabalho docente a partir dos anos 1950, mas principalmente no contexto da reestruturação produtiva do capital e da adoção de políticas neoliberais nos últimos trinta anos. Na referida tese, a pesquisa se fundamentou no materialismo histórico dialético e compreendeu os professores vinculados à SEE-SP na Diretoria Regional de Ensino de Andradina ${ }^{1}$. Foi realizada por meio de questionários estruturados e anônimos para professores em atividade, num total de 128, e com entrevistas orais a três professores aposentados que ingressaram na SEE-SP entre os anos 1950 e 1960, para possibilitar uma maior profundidade temporal ao universo empírico.

Não é novidade que os docentes sofreram, e ainda sofrem, um profundo processo de desvalorização material e social e há muitas pesquisas acerca do trabalho docente, da sua proletarização e precarização, no campo da Sociologia da Educação e na área de estudos de "Educação e Trabalho". A novidade desta investigação, ora apresentada, está na inserção de professores como sujeitos do trabalho no campo da História e, especificamente, da História Social do Trabalho no Brasil. Esta área do conhecimento histórico tem se ampliado nas últimas décadas, a partir da crise paradigmática e das contribuições dos marxistas britânicos, e já não se limita ao trabalhador fabril, englobando trabalhadores sem trabalho, trabalhadores sem salário, e outros mais que emergem, da realidade, para a compreensão teórica. É nesta ampliação que vimos oportunidade de realizar um novo olhar para a experiência docente, sob a luz da centralidade do trabalho e, com isso, contribuir dialeticamente para tal ampliação pois, ao menos na historiografia brasileira, os professores

\footnotetext{
* Brasil. Professora Adjunta na UFMS, Campo Grande-MS; Doutora em História pela UFGD. mariana.esteves@ufms.br

${ }^{1}$ A escolha de Andradina como município para a realização da pesquisa se deu em função da exequibilidade da coleta de entrevistas, sendo devidamente contextualizada no decurso da escrita da tese, tendo em vista as especificidades que a distanciam e a aproximam das diferentes faces da realidade da SEE-SP, sem que elas pudessem gerar discrepâncias determinantes nas análises produzidas. Por não se tratar de uma capital ou grande centro urbano, entendemos que os professores entrevistados não experimentam situações peculiares a estes contextos, todavia, a pesquisa bibliográfica e teórica buscou dar conta das possíveis variações ou mesmo do entendimento que as diferentes faces da realidade paulista não superam a necessidade e capacidade de levantamentos considerados gerais em localidades particulares. Nisso, os jogos de escalas, a dialética e a dimensão da totalidade tornam-se fundamentais na composição das análises. Destaca-se ainda que a rede estadual possui mais de 230 mil professores distribuídos em mais de cinco mil escolas. Em 2013 os dados da SEE-SP apontavam que as seis escolas estaduais de Andradina (cinco urbanas e uma rural) possuíam cerca de 200 docentes e atendiam um total de 4.460 alunos. Apesar do pequeno porte, o município constitui-se como polo regional, inclusive na perspectiva da educação pública estadual, pois sedia uma Diretoria Regional de Ensino englobando outros dez municípios. No âmbito institucional, a Diretoria Regional de Ensino de Andradina constitui-se como a representante legítima da SEE-SP e, portanto, a compreendemos como um importante pilar do contexto político institucional. Criada pela Lei no 5044/58 e instalada no município em janeiro de 1959, hoje ela é responsável por 23 escolas distribuídas em 11 municípios, com 1017 professores no seu total, segundo dados do Departamento de Recursos Humanos do Estado (DRHU), em 2013.
} 
foram relegados ao campo temático do "ensino de história" e, raramente, vistos como trabalhadores ${ }^{2}$.

Observamos que as pesquisas da área da Educação acerca do trabalho docente compreendem uma ampla discussão acerca da natureza do trabalho do professor. Nesse debate, a natureza intelectual do trabalho docente não assegura ao trabalhador à sua percepção de explorado e proletarizado, tendo em vista sua característica histórica, desde os tempos da antiguidade, onde os professores eram, inclusive, escravos, mas considerados privilegiados por não exercerem serviços braçais (MANACORDA, 1996). Outra característica do trabalho docente que baliza este debate é a de trabalhador 'improdutivo', na contemporaneidade, isto é, aquele que não produz mercadorias e mais-valia. Todavia, amparados nos trabalhos de Frigotto e Nicanor Sá, compreendemos que a lógica do capital entranhou-se à escola, inclusive nas formas de divisão e organização do trabalho pedagógico, separando o professor da produção do conhecimento e resultando em proletarização. Isto é, a perda da autonomia é uma característica que se aprofundou no processo do trabalho docente, propiciando, ainda, a alienação. Além disso, a escola, ao servir à reprodução do capital na formação da classe trabalhadora para tal, engendra seu papel na totalidade como parte importante da engrenagem capital, obtendo isso por meio de, entre outras coisas, o trabalho docente. Neste sentido, a pesquisa partiu fundamentalmente da ideia de que o professor é, numa perspectiva de classe social, um trabalhador, tal como os demais trabalhadores da contemporaneidade, mas em virtude de características históricas e imbróglios ainda recentes, não é tratado como tal, nem pela sociedade, pela ciência, e nem por si mesmo.

As visões, representações e idealizações acerca do professor têm dificultado reflexões que o possibilitem pensar sua categoria como fundamentalmente profissional e histórica. Há uma gama de características que se colocam para a atividade docente, centradas principalmente nos aspectos do ensino e aprendizagem, mas para nós, a docência é essencialmente trabalho, no sentido produtivo, reconhecido e remunerado como tal, e entendemos que o caleidoscópio identitário que caracteriza o 'fazer-se' docente é um dos empecilhos à compreensão da dimensão do trabalho docente como central, dentro dos contextos do mundo do trabalho e do modo de produção. Urge, portanto, buscarmos os professores como sujeitos do trabalho, o que acreditamos ter iniciado com nossa pesquisa de doutorado. Nela, observamos como a precarização se engendrou materialmente, a partir de categorias como salários, jornadas e contratos. Somamos a esse tripé histórico as atuais políticas que consideramos piorar as condições de trabalho docente, como bonificação por resultados, além da violência e das consequências na saúde do professor. Além disso, observamos que, a despeito da tradicional resistência docente, com suas históricas organizações de greves, a precarização se expressa por uma crise de mobilização, e é este o tema que viemos aprofundar aqui, neste texto.

Entendemos ainda a categoria docente como uma categoria profissional em luta. Poderíamos discorrer amplamente sobre o conceito de resistência e suas ampliações,

\footnotetext{
2 Esta tese foi explanada e pode ser compreendida a partir da leitura de OLIVEIRA (2016), onde desenvolvemos uma análise historiográfica acerca do professor como sujeito do trabalho no Brasil.
} 
todavia, nossa afirmação se justifica e se exemplifica pela existência e continuidade de greves docentes no país e na SEE-SP. E não raro, na eclosão de greves e manifestações de professores, o que se observa é que muitos setores da sociedade apoiam a categoria, não obstante a invisibilidade destes movimentos nas grandes mídias. Há um certo consenso de que o professorado tem, como grave problema, a questão salarial, símbolo explícito da precarização de onde decorrem outros males que compõem este cenário nebuloso, como a ampliação da carga horária, intensificação do trabalho docente, instabilidade, violência e morbidade. Nestes momentos, a questão salarial fica latente também porque se caracteriza como instrumento importante da disputa contra o Estado, no rol de 'exigências' elencado pelo movimento.

Neste sentido, vale destacar que, historicamente, a resistência docente tem se elevado a patamares mais abrangentes. Ferreira Junior e Bittar nos colocam que a luta docente dos anos 1970 atingiu uma consciência mais notadamente política resultando em uma espécie de compromisso histórico que passaria a acompanhar a identidade docente:

O comportamento social que caracterizava os movimentos grevistas da categoria dos professores públicos estaduais de $1^{\circ}$ e $2^{\circ}$ graus, no final da década de 1970, era do tipo que já engendrava uma consciência da solidariedade de interesses gestada entre todos os membros do grupo social e que questionava, ainda que do ponto de vista econômico, as bases jurídicas do Estado ditatorial brasileiro. Provavelmente, apenas as vanguardas da categoria, em unidades federativas como São Paulo, Rio de Janeiro, Minas Gerais, Rio Grande do Sul, Paraná e Pernambuco, tinham atingido o terceiro momento descrito por Gramsci, isto é, a fase mais abertamente política; e alcançado, portanto, o amadurecimento social necessário para criar as condições organizativas e de direção política para as lutas levadas a cabo pelos professores nacionalmente (FERREIRA JR e BITTAR, 2006: 1167-1168).

Essa consciência política que fundamentava os movimentos grevistas a partir dos anos 1970 perpassou a questão da democracia, compreensível pela conjuntura política ditatorial da época em que emergiu, somando-se à questão da ampliação do acesso ao ensino para as camadas populares de maneira qualificada, pois a expansão do ensino foi produzida de forma eminentemente quantitativa, além das estruturas de gestão do sistema escolar, notadamente antidemocráticas, acentuando-se nas políticas públicas educacionais. Nesse sentido, é possível visualizar os movimentos docentes emergentes no regime militar como amparados em lutas que se ramificavam entre a questão material (salário e condições de trabalho), e uma luta político-pedagógica. Nos anos 1980, a professora Angelina Teixeira Peralva, ao fazer um balanço das lutas docentes, salientou que:

A luta salarial é muito mais importante, sem dúvida, mesmo porque, se o professor da rede pública é tão mal pago, é justamente por servir a uma camada desfavorecida da população. A luta pedagógica e a luta pela democratização da estrutura de poder são fundamentais, porque redefinem o destino social do conhecimento e as bases do seu controle. É também fundamental que alunos e pais de alunos sejam associados a essa luta e, nesse âmbito, os professores têm em mãos um outro poder, que é o de abrir as escolas (e o universo escolar, com 
seus códigos próprios) a uma população que tem procurado garantir, nos bairros populares, o seu direito de acesso à educação. Na capacidade de contrapor uma alternativa à política educacional dominante que, de diversas maneiras, tem reduzido o professor no Brasil a desempenhar um papel de agente do fracasso escolar, situa-se provavelmente o mais alto significado histórico possível do atual movimento dos professores da rede pública (PERALVA, 1988: 66).

Pelos trechos acima expostos, poderíamos considerar que a categoria docente encontra-se fortemente unificada nas lutas por melhorias materiais e na incessante busca pela qualificação da oferta de ensino público no país. No entanto, essa aparente coesão da organização social docente parece ter adentrado à crise representativa que o próprio capitalismo neoliberal provoca, ao fragmentar a carreira, constituir exército de reserva de mão de obra e impor metas e disputas individuais. Com isso, a resistência docente constituiu-se, para nossa pesquisa, como a 'questão da resistência', por suas interfaces com a precarização e o sofrimento docente.

Além disso, outra análise ainda vem problematizar a questão da consciência social dentro da categoria docente, como fragmentada também por geração e origem social. Segundo esta abordagem, os professores primários e secundários constituíam, à época da emergência dos novos movimentos sociais e sindicais, duas gerações diferenciadas por sua origem social. A primeira geração, que ingressou antes ou nos idos dos anos 1970, era constituída de uma camada privilegiada da sociedade, oriunda da burguesia e das classes médias altas, e que sentiu gravemente o processo de proletarização e empobrecimento docente. Esta geração impulsionaria os movimentos docentes sindicais, motivada pelo inventário de perdas e condições de trabalho decorrentes do arrocho salarial e das reformas operadas desde o regime militar.

Aponta-se, então, uma dificuldade de mobilização dada no choque com uma segunda geração docente, posterior a 1970 e oriunda das classes populares, anteriormente excluídas do ensino superior, beneficiárias da relativa democratização do acesso a este nível de ensino, sobretudo dos cursos de licenciaturas curtas e noturnas, em faculdades integradas pulverizadas pelo interior do Estado, a partir das reformas que impulsionaram o ensino superior privado e a baixos custos. Para esses sujeitos, tornar-se professor era ascender socialmente e, inclusive, em termos materiais. Segundo Abramo:

A segunda vertente de formação social do moderno magistério origina-se no processo de massificação escolar inegável nessas últimas duas ou três décadas. [...] Essa segunda parte, através de um processo de mobilidade social, vertical ascendente, provém de camadas realmente populares, ou de camadas de classe média baixa. [...] Essa segunda [geração] - para quem ser professor significa quase o apogeu na escala de ascensão social - passa a ter, diante dos problemas da educação e dos problemas da sua corporação profissional, uma atitude bastante diferente da primeira, que se proletarizou no trabalho. A segunda camada, que talvez hoje, em certos centros urbanos do país, constitua a maioria, tem-se mostrado, de certa forma, conservadora e pouco afeita à luta por 
modificações e transformações na educação e na sociedade (ABRAMO, 1986, pp. 78-79).

Carlos Bauer, em seu "A classe operária vai ao campus" (2010) coaduna com a visão de Abramo, ao argumentar que a origem operária dos professores formados nas últimas décadas provoca uma intensificação do processo de cooptação dos docentes à ideologia hegemônica burguesa em função da ideia de ascensão social que a categoria engendra face à sua origem de classe. Para este autor, ao adentrarem ao grupo de profissionais cujo oficio demanda o ensino superior, inacessível anteriormente à classe operária, os professores tornam-se ícones da mudança social em suas famílias e comunidades e reafirmam o ideário meritocrático imposto pela performance neoliberal, dificultando, entre outras coisas, a mobilização coletiva da categoria.

Mas há, aqui, uma contradição a ser destacada. Quando Perseu Abramo sugere o choque entre as gerações docentes por sua origem social ele afirma, em outras palavras, que a primeira geração, originária (no caso do Brasil) das classes médias, tornar-se-ia a vanguarda da luta sindical, em função de que esta havia perdido status e condições materiais, enquanto a segunda geração, pós-1970, ao ingressar na carreira, havia ganhado status e condições materiais, em relação à sua origem social popular. Isto seria um nó para a tessitura de relações de resistência. É contraditório dizer que será o grupo de origem burguesa o mais combativo em detrimento daquele, cuja história social se alinha à tradição da luta de classes, embora nem tanto no Brasil. Destaca-se ainda que esta primeira geração foi profundamente marcada pelo processo de inserção das mulheres normalistas no magistério (feminização do trabalho docente), em muito ainda desprovidas do ensino superior. No entanto, Hypolito lembra que não se pode perder de vista as contradições, especificidades e os movimentos que constituem essa categoria social, pois apesar de considerar a categoria docente como parte integrante da classe trabalhadora, ressalta as profundas marcas ideológicas e culturais que a caracterizam e que demonstramos brevemente no início deste texto. Para ele "esses possíveis movimentos internos podem estar revelando um coletivo em formação, em luta para se constituir parte da classe trabalhadora, mas que vive uma situação de identidade social contraditória". (HYPOLITO, 1997: 79).

$\mathrm{Na}$ direção destas reflexões, encontram-se os argumentos que justificam as dificuldades de mobilização política docente aos resultados somados e engendrados ainda do próprio contexto de formação docente, uma vez que a pulverização das faculdades noturnas de licenciaturas curtas e privadas, a partir dos anos 1970, assumiria o papel de aceleradora da formação docente inicial (para garantir mão de obra ao mercado em expansão) em uma perspectiva também precarizada, destituída de um corpo teórico e formação política. Estas últimas ficariam vinculadas mais às universidades públicas, concentradas principalmente nos programas de pós-graduação strictu sensu, ainda inacessíveis ao corpo docente nacional. Os professores sofrem da precarização antes mesmo de adentrarem ao mundo do trabalho docente, pois seus processos de formação inicial já estão profundamente marcados pela lógica capitalista do mercado, dificultando, entre outras coisas, uma atuação política reflexiva. 
Não obstante, Ferreira e Bittar (2006) acreditam que a categoria, enquanto ente coletivo, herdou uma tradição combativa que a caracteriza e que se manifesta na continuidade da luta, explicitada (e muitas vezes construída) nas greves. Mas as dificuldades de mobilização na categoria existem, e tanto podem estar influenciadas por tais questões, como também se configurar numa multiplicidade de fatores, que se somam e corroboram com a precarização em uma perspectiva estrutural e estruturante, além de elementos que caracterizam a categoria por esta também ser numericamente gigantesca e diversa $^{3}$. Nesta perspectiva, vale destacar que, no Estado de São Paulo, a categoria já teve dois sindicatos representativos, o CPP (Centro do Professorado Paulista) e a APEOESP (Sindicato dos Professores do Ensino Oficial do Estado de São Paulo).

\section{História dos movimentos docentes na SEE-SP}

O CPP foi criado em 1930 constituindo-se como representante legítimo dos professores paulistas, sobretudo os professores primários, com promoção de atividades recreativas e unidades de assistência aos docentes (VICENTINI e LUGLI, 2009: 124). Apesar de um caráter amplamente assistencialista, a associação orientou campanhas salariais, apoiou a luta docente e abraçou a primeira greve da categoria, em 1963 (PEREIRA, 1969: 180). Hoje, o CPP está vinculado aos professores das centenas de redes municipais, em virtude do nível de ensino que ele abrange representar.

Em 1945, surgiu a APEOESP ${ }^{4}$, como associação, para lutar contra problemas específicos do magistério secundário. Um grupo de trabalho eleito no congresso de sua criação ficou responsável pela elaboração do estatuto da nova entidade, seguido pela eleição da sua primeira diretoria. Foram criadas duas instâncias deliberativas, (Assembleia Geral Ordinária e Congresso) ambas anuais, e a diretoria também era eleita anualmente, compreendendo um início de considerável participação entre professores e dirigentes que, "enxergavam na nova associação, o mecanismo para influenciar em decisões governamentais no âmbito educacional, a fim de verem solucionadas suas reivindicações corporativas" (KAPOR, 2012: 1105). Mas seu início foi marcado pela heterogeneidade e por conflitos internos deflagrados sobretudo mediante às exigências de parte da categoria em relação à realização de concursos públicos pelo governo, o que desagradava parte do professorado (chamados interinos).

A Associação teve cunhada a característica de assistencialista e até governista. Mas vale destacar que seu nascimento, datado de 1945, ajuda a compreender um pouco da característica apontada aqui. Nascida no final do Estado Novo, a APEOESP conviveu por muitos anos com a herança do espectro sindical deste período da história brasileira, em que

\footnotetext{
${ }^{3} \mathrm{Na}$ SEE-SP, segundo os dados oficiais, já somam hoje mais de 230 mil professores distribuídos em mais de cinco mil escolas. Conforme http://www.educacao.sp.gov.br/portal/institucional/a-secretaria/ Acessado em /09/04/2014.

${ }^{4}$ Quando fundada, sua denominação era APESNOESP (Associação dos Professores do Ensino Secundário e Normal do Estado de São Paulo). Apenas em 1973, com a substituição dos termos primário e secundário pelos termos $1^{\circ}$ e $2^{\circ}$ graus, a entidade passou a ser chamada de APEOESP, nome que carrega até os dias atuais.
} 
os sindicatos possuíam relações orgânicas com o Estado e este último tinha um controle considerável na sua gestão (ANTUNES, 1996). Embora o sindicalismo docente tenha suas trajetórias peculiares, o contexto sindical constituído na Era Vargas, até o golpe militar de 1964 (antes da emergência do chamado Novo Sindicalismo) não deixou de ser uma atmosfera da qual a entidade também respirava. Além disso, a associação não tinha estatuto de sindicato pois, à época, era proibida a sindicalização de funcionários públicos ${ }^{5}$. A APEOESP surgiu no final deste ciclo político, num momento de transição, mas que ainda carregava fortes características da fase que seria superada na própria experiência combativa da luta sindical que se seguiria décadas seguintes.

Segundo Tatiana Kapor, que estudou a entidade em seus primeiros anos de atuação, nos anos 1950, a associação se preocupava com as irregularidades que marcavam os pagamentos das aulas extras, atrasos salariais, ausência de reajustes e o início da expansão da oferta de ensino que já apontava descompromisso com a qualidade. No entanto, ao contrário de outros sindicatos operários naquele momento, a APEOESP, por meio de seus dirigentes, mantinha afastadas as perspectivas de realização de greve. Apenas em 1963, após consecutivas derrotas em suas reivindicações e por pressões que incluíam o sindicato dos professores primários, o CPP, a APEOESP concordou em apoiar o movimento grevista que se engendrava entre os professores, tanto primários quanto secundários, conforme a autora:

Os ataques do governador Ademar de Barros se intensificou contra os professores grevistas. Tentativas de ligar a imagem do professor ao profissional que não cumpre sua missão foram feitas. A tentativa era acabar com a greve que atingia praticamente a totalidade das escolas. Em âmbito mais geral, divulgava-se nacionalmente que o país caminhava pra uma desordem. Que existia uma invasão comunista, e comunistas infiltrados no magistério. Para conduzir a greve foram organizados dois comandos de greve, um dos professores secundários e outro dos professores primários, e ambos se organizavam no comando geral de greve que ficavam responsáveis por dirigir as passeatas e ações conjuntas. No dia 21 de outubro, os professores encerraram a greve após negociações com o governo, as conquistas foram de gratificação de $60 \%$ aos professores primários da ativa e os aposentados, $25 \%$ de gratificação aos docentes secundários, integração das aulas extraordinárias à aposentadoria e redução da jornada de 18 para 15 aulas semanais (KAPOR, 2012: 1112).

Mas em função da resistência em apoiar o movimento, a greve de 1963 tem sido historicamente 'apadrinhada' pelo CPP, e a APEOESP não a considera como parte da sua história de organização grevista. Os anos 1970 foram marcados pela agressividade do regime militar frente às associações políticas, com isso, a entidade adentrou em um período

\footnotetext{
5 Após a Constituição de 1988, passou a ser permitida a organização sindical do funcionalismo público e as antigas Associações tornaram-se sindicatos, em que pese muitas manterem as mesmas denominações.
} 
de aparelhamento sindical e ao final dos anos 1970, era alvo de críticas ('peleguismo') ${ }^{6}$, mas já abarcava uma grande quantidade de associados tendo em vista a expansão do ensino secundário. Com as greves deflagradas em 1978 e 1979, após intensas disputas internas, a associação passou por mudanças direcionais, pressionada para que se posicionasse politicamente à esquerda e se aproximasse do movimento operário. Segundo Rosário Lugli, "a partir daí, surgiu no discurso dos professores uma polarização: APEOESP à esquerda e CPP à direita no espectro político" (LUGLI, 1997: 79).

Assim, a década de 1980 marcou a consolidação da APEOESP como representante dos professores da SEE-SP, processo favorecido, por um lado, pela municipalização do ensino primário no Estado, o que afastou definitivamente o CPP da representação dos professores estaduais e as dicotomias intrínsecas nas suas relações com a APEOESP ${ }^{7}$. Por outro lado, a própria associação cresceu politicamente, na articulação de greves e congressos, o que compreendeu o fortalecimento político da representatividade da categoria.

A entidade tornou-se sindicato em 1988, ligado à Central Única de Trabalhadores, CUT, na mesma década em que liderou cerca de cinco greves dentre as quais, em 1989, a maior da história da categoria até então, com 80 dias de paralisação. Nos anos 1990, foram quatro greves $(1992,1993,1995$ e 1998) e, na década de 2000, duas greves (2008 e 2010), nos últimos anos, destacam-se as greves de 2013 e mais recentemente, em 2015. Com exceção dos primeiros anos do século XXI, a categoria construiu um histórico intenso de greves que se alternam em média a cada dois anos, e sobre isso vale lembrar que, no Brasil, embrenhados pela emergência do PT ao poder federal em 2003, os sindicatos e movimentos conheceram, contraditoriamente, um congelamento atitudinal frente a um devir marcado de esperanças que se pronunciavam nas perspectivas políticas nacionais que, contudo, não se concretizaram.

A anomia temporária dos movimentos sindicais caracterizou o primeiro governo de Lula e vale dizer, é ainda um processo em profunda remodelação. Andréia Galvão nos lembra de que este processo esteve vinculado, primordialmente, pela aproximação entre a maior central sindical do Brasil à época - a CUT -, e o partido. A autora, inclusive, contextualizou e justificou sua afirmação, exemplificando:

\footnotetext{
${ }^{6}$ De acordo com D'Araujo, "Peleguismo tornou-se um termo de cunho depreciativo, que designa uma ação conciliatória de representantes sindicais tendo em vista amenizar os atritos entre capital e trabalho" (D’ARAUJO, 2010: 231). Conforme Paula Perin Vicentine, as greves ocorridas no final dos anos 1970 foram deflagradas à revelia da APEOESP pois a Associação encontrava-se, à época, distanciada das bases e das suas lutas, e próxima ao Estado. Assim, os Comandos de Greves de 1978 e 1979 romperam com as lideranças da APEOESP acusando-as de "peleguismo". Sobre isso, ler VICENTINI, Paula Perin. A profissão docente no Brasil do século XX: sindicalização e movimentos. In BASTOS, Maria Helena Câmara \& STHEFANOU, Maria (org.) Histórias e Memórias da Educação no Brasil - século XX. Petrópolis: Vozes, 2005: 336-346.

7 Mais fortemente a partir de meados dos anos 1990, a SEE-SP, comportando-se coerentemente com o processo neoliberal de descentralização do serviço público, passou toda a rede do ensino primário (atualmente Pré-Escolar e Fundamental I) às mãos dos municípios paulistas. Tal processo gerou nova fragmentação da categoria docente e parte dela ficou sob condição contratual de "adida" (emprestada), do Estado ao Município, sem contudo gozar dos mesmos direitos ou benefícios já que cada sistema ou município possui seus códigos e planos de carreiras próprios.
} 
A situação é completamente diferente num governo que a CUT considera seu aliado: a proximidade entre a central e o partido afastou a CUT de manifestações e críticas ao governo, mesmo quando este ameaça direitos dos trabalhadores. Isso fica claro quando se observa a posição que a central assumiu em relação à reforma da previdência, implementada em 2003. Essa reforma gerou grande insatisfação nos servidores públicos, contrários à taxação dos inativos, ao fim da aposentadoria integral e da paridade entre ativos e inativos, bem como à criação de fundos de pensão. Embora a cúpula da central criticasse alguns pontos da reforma, como a taxação dos inativos, e fosse favorável a um benefício de valor mais elevado e a uma previdência complementar pública, procurou preservar o governo de qualquer desgaste, opondo-se à greve que havia sido convocada por entidades de servidores, muitas delas ligadas à CUT, e defendendo, em seu lugar, a negociação dos pontos polêmicos (GALVÃO, 2009, p. 182).

Não obstante, cumpre salientar que as greves também não são as únicas formas de mobilização política do sindicato. A agenda histórica da APEOESP é marcada por forte dinamismo. Os congressos são anuais, com grande presença das centenas de delegados representantes, as campanhas salariais também, e assembleias, ações judiciais unificadas, atos públicos, mobilizações que demandam caravanas que saem de todo o interior do Estado para somar aos professores em frente à sede da SEE-SP são recorrentes ${ }^{8}$.

Contra a consolidação e ação política do sindicato, que desde o final dos 1970 se revelava extremamente politizado (não se limitando às demandas materiais docentes, mas, inclusive, interferindo na pauta social paulista e brasileira, como o apoio à Reforma Agrária e, sobretudo à Escola Pública de qualidade) esteve o governo estadual geralmente conservador e autoritário, com raras exceções. No início dos anos 1980, por exemplo, o governo de Paulo Maluf tentou asfixiar materialmente a entidade, retirando o desconto sindical da folha de pagamento, retomado de fato apenas no governo Franco Montouro. Este quadro piorou, no entanto, na emergência dos governos de explícito ideário neoliberal, ainda em pleno vigor no governo paulista. Desde a ascensão de Covas as medidas de boicote à ação sindical podem ser notadas:

Deve-se salientar que a SEE e o governo buscaram desestruturar o sindicato e enfraquecê-lo frente à comunidade escolar e à população em geral. O governo permaneceu inflexível às negociações com o sindicato durante toda a gestão. Não foi incomum a SEE utilizar-se da imprensa para informar importantes medidas que interferiam na vida escolar, anulando a APEOESP como interlocutora da categoria. Além disso, desferiu ações que atingiram as bases de organização do sindicato. Conquista da APEOESP durante o governo Montoro, a participação dos professores em atividades sindicais como encontros, seminários, reuniões de representantes de escola, eleições do sindicato, entre

\footnotetext{
${ }^{8}$ Neste item, vale a pena consultar um histórico de ações e conquistas produzido pelo próprio sindicato, disponível em http://www.APEOESP.org.br/o-sindicato/historia/
} 
outras, não constavam como faltas. Em 1996, a SEE nega o abono de ponto aos professores durante as eleições gerais da entidade, que ocorreriam, desde então, com urnas volantes. (GOULART, 2004: 174).

Na dinâmica política e social em que estamos engendrados desde os anos 1990, urge destacar o vigor da APEOESP como dinâmica e forte, dentro da teia associativista da sociedade civil organizada, ainda que seja preciso admitir a oscilação do papel político e representativo do sindicato como uma marca nas relações trabalhistas dentro da SEE-SP e outras instituições. Há um quadro de tensões e desmobilização, pautado ainda em disputas internas e crises de representatividade. Há, por exemplo, inúmeras discussões quanto à legitimidade dos conceitos e preceitos educacionais pensados em âmbito sindical pelos próprios associados, já que as lutas da APEOESP, enquanto sindicato de profissionais da educação, carregam, no bojo dos compromissos políticos, as dimensões educativas intrínsecas ao escopo profissional dos trabalhadores que a compõem e que por ela são representados. Reni Gomes da Silva, ao estudar estes embates, critica as posições do interior do sindicato que defendem a atuação da APEOESP como restrita ao universo das condições materiais de trabalho e dos direitos trabalhistas, e lembra que o compromisso por uma educação pública de qualidade deve estar acima de todas as prioridades sindicais (SILVA, 2008).

Além disso, para não nos furtarmos ao nosso olhar empírico, precisamos lembrar que o sindicato, apesar de se constituir como um dos maiores do Brasil, do ponto de vista numérico (e em proporção ao território que atua) ${ }^{9}$, não contempla a totalidade dos professores da rede estadual paulista. Muitos milhares de docentes, sobretudo ingressantes, não são sindicalizados. Isto não significa dizer, a priori, que estão à direita do processo de lutas docentes no Estado de São Paulo, até porque as relações entre a sindicalização e a militância política ou social não são automáticas, diretas ou óbvias, apesar da história do sindicalismo brasileiro estar vinculada ao movimento operário em suas mais diversas fases e, sobretudo, no pós-1964, com a emergência discursiva e prática do sindicalismo combativo denominado de Novo Sindicalismo ${ }^{10}$. Entendemos que o engajamento preconiza não apenas a ligação concreta do trabalhador à sua categoria (perpassada pelas relações de emprego), ou ainda uma consciência social abstrata, mas também o sentimento de pertença e identidade, bem como as condições objetivas que possibilitam essa identidade.

\footnotetext{
${ }^{9}$ Atualmente a APEOESP possui cerca de 180 mil sócios, de um total de 230 mil servidores da categoria, tem sua sede central na Capital, São Paulo, e está representada em 93 regiões do Estado onde mantém subsedes 10 na Capital, 17 na Grande São Paulo e 66 no Interior, incluindo uma em Andradina-SP. Não é possível, todavia, afirmar ser, ou não, o maior sindicato do Brasil, tendo em vistas outras varáveis, como as relações entre categorias federais (sindicatos de policiais federais e bancários), suas composições e uniões entre sindicatos estaduais e até locais, fazendo variar a representatividade em número e abrangência territorial.

10 Os percursos discursivos e aproximações políticas do sindicalismo brasileiro, inclusive do Novo Sindicalismo, e suas relações com a esquerda nacional, podem ser compreendidos através do texto de SANTANA, Marco Aurélio. Entre a ruptura e a continuidade: visões da história do movimento sindical brasileiro. Rev. bras. Ci. Soc., São Paulo, v. 14, n. 41, p. 103-120, Out. 1999.
} 
Face às políticas contratuais de cunho neoliberal, o corpo docente da SEE-SP é marcado por fraturas e fragmentações contratuais importantes, com expressivo número de professores não efetivos, sem estabilidade e contratados temporariamente e que, em grande parte, não estão ligados ao sindicato (FERNANDES, 2010: 102). Isto também não significa dizer que não se sintam representados por ele. Neste momento, é possível dizer, pelo menos, que ambos os grupos sofrem os reflexos da incessante precarização do trabalho, vivenciam e experimentam o mal-estar docente, adoecem e retornam à labuta, e estão em luta, nas suas mais diversas faces, seja ela sindical, organizada, seja ela cotidiana, na incansável tentativa de fazer valer, ainda que em sala de aula ou pelos corredores, velhos compromissos. Vejamos como isso se manifesta do ponto de vista empírico.

\section{A resistência docente entre os professores de Andradina - SP}

Do ponto de vista histórico, em relação às memórias dos professores aposentados, a questão da resistência aparece bastante difusa. Ainda, cabe dizer, com exceção de um professor (Benedito), as duas professoras (Marisa e Maria do Carmo) se aposentaram em 1985, antes mesmo das associações conquistarem a condição de sindicatos. Os professores Marisa e Benedito foram, e ainda são, filiados à Apeoesp, apesar deste último afirmar "Infelizmente eu sou associado à Apeoesp. Eu digo infelizmente porque eu não concordo com o que eles estão fazendo com a educação". Já a professora Maria do Carmo é vinculada ao CPP, mas afirmou que se filiou depois da aposentadoria, para gozar dos serviços oferecidos na cidade onde reside atualmente, São José do Rio Preto - SP. As duas professoras afirmaram ter participado de greves, e o professor Benedito sentenciou: "Nunca participei de greve nenhuma. Sou meio conservador, meio direitista".

Para a professora Marisa, a greve era o meio pelo qual se podia, naquele tempo, lutar para a melhoria das condições salariais, ainda que já percebesse, no movimento, a questão da unidade da categoria. Ela afirma ter participado de várias greves e lembra como eram os movimentos:

Olha, era bem, assim, organizadas. A gente ia na escola, muitas vezes ficava lá, sem o aluno, né, mas a gente fazia a hora lá, o tempo né, e nos reuníamos né, pra debater, e muitos professores não queriam participar, né, a gente sempre teve uma falta de... coleguismo, seria? Uma falta de cabeça assim, de idealismo de classe, foi bem difícil isso eu acho, mas eu achei que valia a pena, porque era a única forma né, da gente receber um aumentozinho, alguma coisa.

A professora Maria do Carmo, por sua vez, demonstrou constrangimento ao rememorar sua participação em greves, de modo que seu depoimento parece sempre oscilar entre a vergonha e o orgulho de ter experimentado isso:

Ah não, isso eu não vou contar não (risos). Ah, mas foi muito divertido, só que eu não me lembro que época que foi e nem o governo que foi, só me lembro que foi por causa do Maluf. Ele não era governador mais, ele já tinha saído, mas eu não sei o porquê, a ... ai não vou citar o nome, a secretária: "Maria, você já tá 
pra aposentar, não faça isso, vai te atrapalhar!" Eu falei: "Não, eu quero aposentar com o meu salário justo, vou entrar sim!" Eu fui distribuir panfletinhos lá naquela praça. Certeza que falaram "ah essa velha aí..., tá na hora de aposentar e ainda tá distribuindo papelzinho aqui pra nós". Mas é...(...) É, melhoria salarial. Eu não me lembro, pra você ver como é que minha cabeça tá ruim, eu me lembro que era eu e uma outra colega, eu falava "vamos ficar nós duas juntas, porque nós já estamos na hora de aposentar, e a gente fica um pouco, vamos dar força pra essa turma, que tá mais fraca né, tá começando agora". Então todo mundo se animava, porque, "nossa, vocês vão, então nós vamos também". E isso foi bom, pra mim foi bom (...) Ah, isso aí eu não podia contar né (risos) (...) O que eu me lembro, ah eu não me lembro assim de falatório, eu me lembro só da distribuição de papeis. Eu falei, "meu Deus, as crianças em casa e eu aqui na rua, andando sem fazer nada, e podia tá em casa né... (risos) e sem aula, e depois a gente teve que repor as aulas. Eu não repunha né, porque eu falei, fiquei em greve e isso é greve, eu ia lá, porque tinha que voltar e dar aula, eu voltava e falava pros alunos "vocês não venham, porque se vocês não tiverem aqui eu não posso dar aula", então os alunos não iam também.

As professoras não rememoraram os temas presentes nos referidos debates, ou 'falatórios', mas salientaram a questão salarial como motivadora para a participação no movimento. Também podemos destacar que a professora Maria do Carmo sugeriu ter sido constrangida a não participar. Isso nos leva a crer que, vinculadas ao ensino primário em toda a sua dimensão de docilidade propagada, estas professoras experimentaram o enfrentamento. Não nos cabe aqui medir o nível de conscientização social de suas participações em greves, mas reforçar um certo pioneirismo feminino e político daquelas que, levadas ao magistério em função de suas condições sociais e sexuais, de gênero, no que concerne à divisão do trabalho, as professoras que aqui se colocaram, novamente em uma situação de exposição, protagonizaram situações de enfrentamento, de expressões agudas das lutas sociais, tal como concebemos a greve.

Ainda, a negativa da participação em greves por parte do professor Benedito não nos apontou uma enorme contradição. Sua clareza ao se referir ao posicionamento político é imensamente explicativa, do mesmo modo que as professoras justificaram sua participação por causa dos salários. Hoje, nos parece, muitas outras questões se interpõem à participação dos professores nos movimentos de paralisação e greves.

No que tange ao cenário atual, entre os professores em atividade na SEE-SP em Andradina, sobre representação trabalhista e resistência, obtivemos o seguinte gráfico: 


\section{Gráfico 1) Sobre representação e resistência - Professores Estaduais de Andradina}

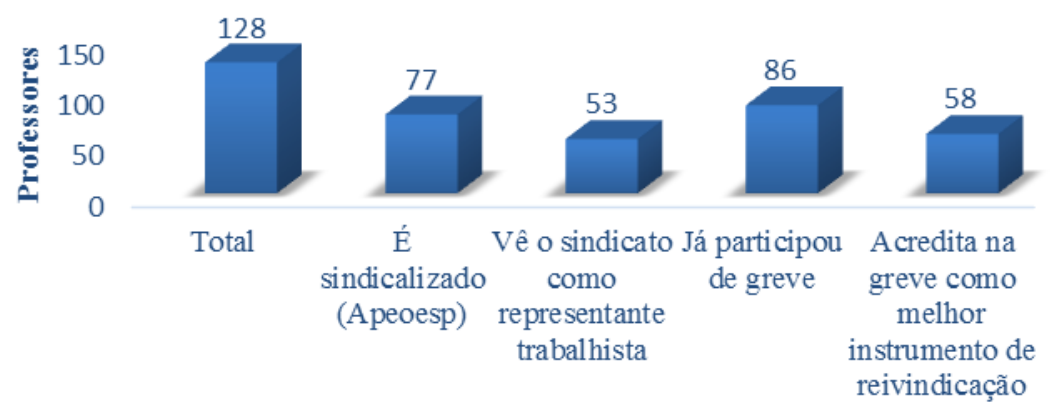

Os professores das escolas estaduais de Andradina manifestaram empiricamente o que observamos na pesquisa bibliográfica, do ponto de vista da crise de representatividade da categoria, não obstante envolver um dos maiores sindicatos da América Latina ${ }^{11}$. Isto é, apesar da maioria dos professores ser sindicalizada, perfazendo $60 \%$ dos docentes, apenas $41 \%$ entende o sindicato como instrumento legítimo de representação dos trabalhadores docentes.

Evidentemente, muitas podem ser as variáveis desta conjuntura, no sentido de expansão ou retração destas estatísticas, a depender dos contextos em que se situam nossa análise, seja em relação a outros sindicatos ou categorias, seja no que tange a circunstâncias em que estejamos a observar tais relações, pois estes números podem, eventualmente, variar após uma greve mal sucedida, ou após um grande concurso público com a adesão de novos trabalhadores. Cabe salientar, todavia, que entendemos que os resultados alcançados de forma empírica dificilmente estariam invertidos em sentido, pois expressam ainda a conjuntura geral deste início do século XXI, de atmosfera marcada por políticas neoliberais a endossar a flexibilização produtiva e, no caso paulista, com um governo estadual reconhecidamente entusiasta de tais políticas. O ideário neoliberal paulista reflete tendências mundiais e baliza discursos "empreendedoristas e anti-sindicais", que legitimam a retirada de direitos conquistados e repressão às lutas e manifestações de trabalhadores. Neste sentido, e porque não nos preocupamos demasiadamente com pequenas variações quantitativas, mas com tendências, consideramos que as respostas docentes confirmam nossas hipóteses de refluxo da importância do sindicato como espaço de luta e representação política do trabalhador neste contexto neoliberal.

Nesta direção, 42 professores indicaram outras funções como primeiras dos sindicatos $(32,8 \%)$, doze afirmaram que sua principal importância é a de oferecer melhores serviços que o Estado, entre eles o plano de saúde. Outros 21 professores assinalaram que o sindicato significa um custo desperdiçado e nove indicaram que a APEOESP tem 'outras' funções importantes que não a representação trabalhista nem oferta de serviços. Ainda, 33 professores se abstiveram nesta questão (8.1.3 do Questionário), a maioria porque anteriormente assinalou que não é sindicalizado.

\footnotetext{
${ }^{11}$ De acordo com a própria instituição; In: http://www.apeoesp.org.br/o-sindicato/missao/
} 
Neste sentido, dentre os 128 professores consultados, somam-se 48 não sindicalizados $(37,5 \%)$, dentre os quais nove afirmaram que já foram filiados a APEOESP, mas se desligaram. Ainda vale destacar que nem todos os 23 professores Categoria $\mathrm{O}^{12}$ estão nesta lista de não sindicalizados, como pensávamos inicialmente. Os professores contratados temporariamente podem e têm se sindicalizado, ainda que de forma tímida. Dos 48 não sindicalizados, apenas 15 são Categoria $\mathrm{O}$, isto é, oito professores sem nenhuma estabilidade estão vinculados ao sindicato e seis deles o consideram importante para representação trabalhista. Três professores não responderam acerca de serem (ou não), sindicalizados (Questão 8.1 do Questionário).

Mas resistência não se resume à sindicalização. A despeito de serem, ou não, vinculados ao sindicato, ou de compreenderem, ou não, seu sindicato como legítima representação trabalhista da categoria, a maioria dos professores das escolas estaduais de Andradina afirmaram já ter participado de greves e manifestações. Entre os 128 professores, 86 disseram ter atuado em pelo menos uma greve durante a carreira $(67,2 \%)$, frente a 38 docentes que informaram nunca ter se envolvido nestes eventos (29,6\%). Aqui também foram três professores a não responderam a questão (8.2 do Questionário).

Compreendemos as greves como experiências de classe, de luta dos trabalhadores, com uma carga histórica importante a oportunizar situações coletivas que constroem consciência e solidariedade, pela união e pelos antagonismos que nela se vislumbram. A greve tem sido, do ponto de vista histórico, o aporte de negociação mais recorrente da categoria e portanto, tomamos aqui as relações entre os sujeitos, o trabalho docente e as greves como um fio condutor para pensarmos o agir de classe entre os docentes, o fazer-se coletivo, de resistência, como afirmou Lenin ao discutir a importância dessas manifestações:

Nos tempos atuais, pacíficos, o operário arrasta em silêncio sua carga. Não reclama ao patrão, não reflete sobre sua situação. Durante uma greve, o operário proclama em voz alta suas reivindicações, lembra aos patrões todos os atropelos de que tem sido vítima, proclama seus direitos, não pensa apenas em si ou no seu salário, mas pensa também em todos os seus companheiros que abandonaram o trabalho junto com ele e que defendem a causa operária sem medo das provocações (LENIN, 1899, s/p)

A princípio, algumas contradições se expressam no que tange aos sentimentos docentes sobre tais movimentos, pois ora os sujeitos revelam uma vitalidade na prática de resistência por meio desse aporte, ora se manifestam contrariados e discordantes sobre o

\footnotetext{
${ }^{12}$ A SEE-SP possui uma variedade de tipos contratuais para professores, entre elas, as mais comuns são os professores Categoria A, efetivos concursados com estabilidade garantida em estatuto, e os professores Categoria $\mathrm{O}$, contratados temporariamente por tempo determinado, com menos direitos trabalhistas e que cumprem interstícios contratuais de 40 a 200 dias inviabilizando a conquista da estabilidade jurídica contratual. Para melhor compreensão acerca das variedades contratuais da SEE-SP e o processo de flexibilização de contratos de trabalho, recomendamos: SANTOS, Edson Segamarshi. A situação funcional dos professores da rede estadual paulista: problemas de admissão, seleção e dos concursos públicos (19762010). Tese (Doutorado em Educação). Pontifícia Universidade Católica de São Paulo. São Paulo, 2012.
} 
fazer-se de greves e manifestações e, veremos, na sequência, que a contradição será uma categoria sempre presente nesta discussão, o que, para nós, enriquece o debate.

Apesar da maioria ter participado, apenas 58 professores afirmaram que concordam com as greves docentes como estratégia de reivindicação (45,3\%). Afirmamos que é contraditório porque há uma inversão na lógica da participação e concordância com a greve. Dos 38 professores que informaram nunca ter participado de greves e manifestações, apenas 11 discordam desse recurso como instrumento da luta trabalhista, isto é, mesmo não tendo participado, 27 docentes acreditam na greve como melhor instrumento. Com isto, temos um aumento da relação de professores que, apesar de terem se engajado em greves e manifestações, não concordam que este seja um instrumento adequado da luta docente. De forma geral, isso corresponde à opinião de 60 professores entrevistados, dentre os quais 49 já atuaram em greves e/ou manifestações. Dez professores não responderam esta questão (8.4 do Questionário).

Isto pode ser desvelado quando observamos as formas pelas quais os docentes rememoram suas experiências de greves. Diferentemente das lembranças desveladas pelas professoras aposentadas, a frustração, o cansaço e as perdas são elementos que surgem em diversos depoimentos. Dentre os 86 docentes que participaram destes movimentos, 64 manifestaram uma memória negativa sobre eles. Apesar da diversidade de motivos explicitados pelos professores, pois a questão era aberta (8.3.3 do Questionário), os relatos evidenciam duas grandes faces da opinião docente. A primeira delas é a impotência do movimento diante do aparelho repressor do Estado. A segunda, com mais força, pois se manifestou em número maior de relatos, é o problema da articulação e da (des)união dentro da categoria.

Na primeira, ganhamos uma dimensão do quão autoritária e até violenta tem sido a repressão contra os movimentos de greve dos servidores públicos paulistas, fazendo com que os trabalhadores temam à iminente asfixia material causada por prováveis cortes salariais, como se expressou a professora que relatou: "Antes, a greve era importante, fazia a diferença. Hoje é apenas prejudicial ao professor, pois temos muitos prejuízos. O governo detém o poder, são mais de 20 anos. Quando deveríamos mudar, não conseguimos, penso que a resposta deve ser na urna" (Questionário 16).

A professora do questionário 88 dialogou nesta mesma direção ao dizer que o movimento era "válido, antigamente, porque podíamos repor e não havia desconto salarial. Atualmente desconta-se tudo. Só há perdas". Nestas falas, também é possível perceber como o sentimento pela greve se altera com a dialética do tempo na memória. Isto é, estes e muitos relatos revelam um olhar mais convergente a este aporte de negociação/resistência quando se trata de um passado mais remoto, em uma memória mais relativizada pelo passar do tempo e o recontar das histórias, enquanto que a lembrança recente se manifesta traumatizada pela perda, já que ela ainda pode ser sentida como prejuízo real.

Entendemos, por um lado, que há um esforço da memória em se desenhar em contornos que corporifiquem as idealizações e identidades sociais dos sujeitos que experimentam lutas e situações coletivas. A memória, segundo Maurice Halbwachs, mesmo que não se torne invenção, se delineia no afetivo-seletivo, e quando rememorada, a lembrança "é em larga medida uma reconstrução do passado com a ajuda de dados 
emprestados do presente, e além disso, preparada por outras reconstruções feitas em épocas anteriores e de onde a imagem de outrora manifestou-se já bem alterada" (HALBWACHS, 2004: 77). Isso contribui para compreendermos a nostalgia frente aos movimentos mais remotos, em contraposição às greves atuais, como a lembrança da docente que afirmou que "greve boa foi a de 1993!!". A mesma professora afirmou ter participado das greves de 1993, 2008 e 2010. (Questionário 108).

De acordo com a APEOESP, o desconto salarial em greve não é uma atitude recente, exemplo é a greve de 1979, que sofreu forte repressão por parte do governo de Paulo Maluf, incluindo "descontos dos dias parados" ${ }^{13}$.Cabe lembrar, ainda, que as experiências de repressão/escassez geradas em cada momento histórico podem variar e que, na atual conjuntura, temos um quadro de professores onde, como vimos, mais da metade possui empréstimos e financiamentos, tornando tais vivências possivelmente mais críticas, o que também poderia justificar o reordenamento da memória acerca da greve.

Por outro lado, corroborando com os caminhos trilhados pelas memórias dos professores ativos participantes da pesquisa, o que se evidencia no histórico dos movimentos é que a precarização do trabalho operada sobretudo nos últimos quatro governos paulistas veio acompanhada do fortalecimento de estruturas de controle, repressão e intransigência no diálogo com os trabalhadores. Assim, a ideia de prejuízo se manifestou em dezenas de relatos docentes, evidenciando que, guardadas as proporções da memória e seus possíveis relativismos, as perdas materiais dos trabalhadores em greve são concretas e tem se tornado, ao longo do tempo, motivos de afastamento dos professores aos movimentos, mesmo como justificativas secundárias, conforme sugere o relato da professora: "Minhas participações me deixaram com sabor de derrota pois, além de perder salário e quebrar o bloco da licença-prêmio, não foi conseguido o objetivo da valorização profissional com salários dignos e cumprimento da Constituição Federal" (Questionário 101). Na mesma direção somamos o depoimento da professora que afirmou que "O docente possui muito medo. O governo, a instituição aterroriza a categoria, ameaçando descontos e perdas salariais e eu mesma, como docente, me sinto impotente para mudar a nossa história" (Questionário 110).

O prejuízo material vem acompanhado, muitas vezes, do sentimento de medo e humilhação, bem como da revolta, frente à violência sofrida, pois a repressão às greves docentes não se limitam aos cortes de salários e prejuízo material. Há um prejuízo emocional, um desgaste perceptível. Muitos docentes rememoraram com tristeza suas experiências de greve ao suscitar os momentos de violência, como a docente que relatou: "Uma vez participei de uma passeata, em plena Avenida Paulista e os policiais correram atrás de nós professores. Foi uma experiência horrível” (Questionário 37).

Com efeito, prejuízos materiais se somam aos emocionais neste retrovisor docente das greves, como relatou a professora que sistematizou suas consequências da participação de três delas (1998, 2007 e 2010), elencando que sentiu "muito esforço e estresse, muita insegurança e tensão. Luta, mas sem retorno, e falta de dinheiro pelos descontos pós-greve" (Questionário 95). Mas os resultados emocionais parecem repercutir no longo prazo. Uma

\footnotetext{
${ }^{13}$ Dado extraído de http://www.apeoesp.org.br/o-sindicato/historia/
} 
docente que afirmou ter participado de movimentos de greves passadas já há algum tempo (não se lembra) advertiu que "foi horrível, você se sente um trapo, e vulnerável" (Questionário 96). É possível inferir que tais experiências, ao serem rememoradas nestas perspectivas, como humilhantes e fracassadas, contribuem para o enfraquecimento das articulações de greve ${ }^{14}$.

Na segunda acepção, ainda relativa à memória (negativa) sobre a greve, os professores apontam a falta de união entre os docentes e, inclusive, dentro do sindicato, como marcos de suas opiniões e experiências no fazer-se de greves e manifestações. Tal menção já havia sido feita pela professora aposentada, Marisa, sinalizando que a questão não é nova. Dentre os professores em atividade atualmente, são dezenas de relatos a sugerirem que a falta de união e/ou pequena adesão dentro da categoria atrapalhou (e atrapalham) os movimentos, como ressaltou a professora ao afirmar, sobre a greve, que "é um movimento que não reúne o número suficiente de professores para lutar por uma valorização dos docentes" (Questionário 14). O professor do Questionário 118 informou que, por suas participações nas greves, que foram muitas desde sua entrada na SEE-SP em 1989, aprendeu que "a classe é fragmentada e os objetivos a que se quer alcançar ficam capengando no meio do caminho". Nesta acepção, os professores horizontalizaram os problemas dos movimentos docentes, deslocando a questão da SEE-SP/Estado/Governo para os próprios professores, e consideram esse aporte de negociação como algo obsoleto, que já funcionou mas deixou de funcionar, e deveria ser superado.

Neste diapasão, o sindicato também emerge como problema, oscilando entre relações conjunturais e estruturais (resultantes do neoliberalismo, por exemplo) e fragmentações internas (ainda na ênfase da união da categoria). Nesse sentido, um docente, ao citar o enfraquecimento do sindicato dentro desse contexto de menor mobilização, ponderou que "no passado, havia maior engajamento, sentia o sindicato mais atuante e presente, verdade que as mudanças do mundo do trabalho enfraqueceram os sindicatos" (Questionário 65).

Ainda, com mais recorrência, o sindicato é citado por muitos professores como espaço de disputas político-partidárias entre grupos da categoria. Uma professora, ao referenciar suas experiências de greve, afirmou que "no passado, era para o bem da base docentes. Hoje é política - PSDB X PT" (Questionário 55). De forma semelhante se manifestou o professor que apontou "Falta união da categoria, por vezes manipulada pela disputa política dentro do sindicato" (Questionário 27). Seja no campo individual da conduta dos sujeitos, seja no bojo da organização docente coletiva, a questão da desarticulação da categoria está posta na memória dos professores que participaram dos movimentos de greves e manifestações.

\footnotetext{
${ }^{14} \mathrm{Na}$ mais recente delas, ocorrida em 2015, (a mais longa da história da categoria, com 93 dias, de 13/03 a 13/06), a maioria dos professores estaduais de Andradina não aderiu, basta dizer que os questionários foram aplicados nas escolas estaduais no período da greve, e em todas as escolas visitadas os professores informaram que paralisaram apenas um dia (13 de março), mas que não fariam a greve em virtude das justificativas que aqui se expõem. É possível compreender que os professores ressaltaram suas memórias e avaliações negativas de greves face a uma defesa da decisão de não aderir ao movimento que estava em curso no momento da aplicação da pesquisa, embora não tenham mencionado.
} 
No âmbito dessa memória de movimentos passados, destacam-se experiências onde professores explicitam e justificam essas opiniões. Assim temos o relato da professora que, apesar de ter participado de quatro greves, afirmou não concordar mais com esse tipo de movimento justificando-se: "Parei, mas muitos colegas não. Fui a São Paulo, mas de nada adiantou. A comunidade, os pais, não apoiaram e nem participaram” (Questionário 21). Como o dela, destaca-se o depoimento da docente que, ao rememorar suas participações em duas greves, lembrou que "Na primeira greve, tive uma boa impressão. Na segunda, alguns colegas justificaram as faltas com licenças médicas. Confesso que me senti muito frustrada com os colegas" (Questionário 94).

Nesta direção também se exemplifica o relato da professora que participou de uma única greve na SEE-SP, no ano de 2007, e não voltou a se engajar nos movimentos seguintes já que sua experiência "foi frustrante, pois foram poucos professores que aderiram à greve, tivemos que repor as aulas e nos dias de reposição sempre aparecia um professor que não aderiu a greve, com desculpas, só para ver se estávamos repondo" (Questionário 113).

Neste momento da análise, podemos localizar outros limites e contradições, os pontos de enraizamento do individualismo e da competitividade neoliberal. Dos 96 professores que afirmaram já ter se engajado, apenas 15 docentes rememoraram positivamente suas experiências de movimentos de greves e manifestações, como situações de classe, onde experimentaram lutas coletivas ${ }^{15}$. Relatos como da professora que admitiu ter sentido "a emoção em poder participar, de reivindicar por melhores condições de trabalho e financeiras" (Questionário 7) e do docente que avaliou, sobre os movimentos em que participou: "Eu gostei. Mostrou união. Foi emocionante” (Questionário 38), constituem um contraste tímido dos sentimentos da grande maioria dos professores consultados.

Nesse contraste, importa-nos observar por onde se espreitam os pontos de vista, aparentemente eivados pela condição de sujeito coletivo, como do docente que acrescentou que gostou de ter participado de greve pois "ampliou minha visão sobre a categoria" (Questionário 49) e da professora do Questionário 58, ao relatar sobre sua adesão às greves como "Emocionante ver a avenida paulista lotada de professores reivindicando seus direitos, mesmo com a cavalaria causando tumulto", ela participou de todas desde que entrou na SEE-SP em 1991, com exceção apenas da última, de 2015.

Um docente compreendeu, como resultado de suas participações nas diversas greves, que o movimento é "um momento de reflexão e esclarecimento sobre seu valor como profissional" (Questionário 97). Outro depoimento caminha nesta direção, evidenciando engajamento e coletividade. A professora, ao afirmar: "Sempre participei ativamente, fazendo parte do comando de greve, tentando conscientizar os professores e toda semana ia para São Paulo nas Assembleias" (Questionário 40) demonstra que as greves ainda podem significar momentos de organização, negociação e conscientização coletiva. Nestas brechas, tão tímidas por serem minoria, buscamos oxigenar o papel da

15 Além disso, 49 docentes não relataram nenhuma experiência ou memória de greve, ou porque não participaram ou porque se abstiveram de responder. 
greve como experiência de classe. Ela seria um importante momento coletivo, a luta com identidade de classe.

Apesar disso, as relações entre identidade e consciência de classe não são simples e não podem ser resumidas de forma simplista. Nestas ocasiões, isto é, nas greves, luta-se muitas vezes contra os efeitos da exploração, e não às suas causas (MARX, 1982), e não seria cabível buscar tal relação nos depoimentos docentes, porém, ao compreendê-la como um momento de fomentação da consciência social coletiva, de negociações e antagonismos de classe, essa perspectiva se confronta com a recorrência de caráter individualista manifestado na maioria dos depoimentos dos docentes participantes da pesquisa, revela uma antítese colocada pelos sujeitos. Ou seja, no aspecto da contradição, trata-se de evidenciar um número expressivo de sujeitos que participam, vivenciam e constroem experiências agudas de classe (como a greve) mas não demonstram ou rememoram tais experiências como momentos possíveis da constituição (mesmo que processual) de um fazer-se coletivo, de um devir conjunto e solidário, de um fortalecimento da identidade coletiva do grupo. Ao contrário, a greve constituiu, para nosso universo empírico, situações de fraturas do professorado.

Somando ao debate as contribuições de E.P. Thompson, com os elementos acerca da consciência de classe (aparentemente ausente nos objetos de acusação dos professores ao apontarem a falta de união da categoria), esta contradição se torna ainda mais explícita. Para este autor, tanto classe quanto consciência são processos históricos resultantes das reiteradas experiências de classes pelas quais os sujeitos passam no bojo das relações produtivas e que, culturalmente, também se apropriam. Para Thompson consciência de classe "é a forma como essas experiências são tratadas em termos culturais: encarnadas em tradições, sistemas de valores, ideias e formas institucionais" (THOMPSON, 1987: 10).

A consciência, portanto, se relaciona às percepções dos sujeitos face às situações de classe e de antagonismos sociais e liga-se (tanto quanto alimenta-se) gradualmente ao potencial de articulação e mobilização coletiva, pois se refere a "consciência de uma identidade de interesse entre todos esses diversos grupos de trabalhadores, contra os interesses de outras classes. E (...) no crescimento das formas correspondentes de organização política e industrial" (THOMPSON, 1987:17). Então, como compreender que essa consciência de caráter social e coletivo se apresenta em alguns momentos/temas (e aqui cabe destacar que isso ocorreu quando investigamos sobre a bonificação por resultados) e, em outros, aparentemente mais suscetíveis ao seu desenvolvimento (greves), não se apresentam, ou surgem em minoria?

Acreditamos que os olhares docentes perpassam e oscilam nos meandros da solidariedade e consciência, mas por vezes caindo nas armadilhas neoliberais de individualizar as responsabilidades. Quando se trata da política do bônus, as relações sociais antagônicas parecem mais evidentes do ponto de vista hierárquico, pois os docentes gozam ou sofrem consequências das ações arbitrárias do Estado que, de forma injusta, nas palavras dos docentes entrevistados, distribuem sem critérios os prêmios ou punições aos docentes, e estes últimos não possuem um controle sobre tais ações. Quando se trata das greves, não somente o Estado surge como responsável pelo fracasso, pelo cansaço ou decepção, pois a força do movimento depende ainda da proporção de adesão dos 
professores, de suas condutas individuais e seus sacrifícios pessoais para somarem ao coletivo.

O aumento da dimensão do fator de sacrifício individual em contraposição às formas de repressão do Estado, no entanto, pode estar estritamente relacionado às próprias estratégias de repressão. O ideário neoliberal incentiva o micro-olhar, a desconexão das conjunturas e estruturas, o individualismo e, ao que os depoimentos nos sugerem, torna-se mais difícil para os docentes enxergarem as estruturas agindo quando os sujeitos estão tão próximos, substituindo eventualmente os grevistas para complementar a remuneração, observando a reposição do outro, lançando mão das licenças em tempos de greve. Afinal, a consciência de classe não é linear e perpassa dialeticamente pelas necessidades de sobrevivência material. Cássio Hideo Diniz Hiro, em sua dissertação de mestrado, procurou compreender os movimentos docentes em Minas Gerais no complexo processo de constituição social da categoria, encontrando as mesmas contradições que dispusemos aqui. Sobre isso, ele considerou:

Em muitos casos podemos observar que as greves e as ações de massa dos trabalhadores representam, de fato, o desenvolvimento, na prática, de uma consciência coletiva daqueles que nelas participavam. A identidade dos sujeitos pertencentes a uma mesma categoria, e, possivelmente, o reconhecimento de uma classe social, são marcas visíveis desses processos. (...) Ao mesmo tempo podemos observar certos conflitos e contradições existentes em seu próprio interior, como por exemplo, a divisão entre os grevistas e os fura-greves, durante e depois do movimento paredista. Conflitos, estes, que não são exclusivos dos docentes, mas também de várias outras categorias de trabalhadores. Contradições que se apresentam entre a solidariedade e o conflito, em um processo dialético que, muitas vezes, desenvolvem-se e podem apontar a superação do estado atual em que se encontra uma classe social. Uma possível consciência de classe pode se desenvolver e se constituir em meio a essas contradições que permitem, aos poucos, a superação de uma falsa consciência, caso ela se apresente de fato. Neste caso, é importante compreender que a história social se desenvolve de forma processual, com seus ascensos e refluxos, com avanços e retrocessos, que não podem ser observados de modo cartesiano e linear (HIRO, 2012: 127-128).

É nesta perspectiva que empreendemos nosso olhar sobre as memórias docentes no que tange às greves e às contradições inerentes a elas. Se, de um lado, temos que as greves histórica e teoricamente se constituem como experiências de classes, matéria prima de sua consciência, elas, por outro lado, podem motivar novas fraturas, sobretudo opondo aqueles que participam daqueles que não se engajaram, mesmo que estes últimos estejam agindo (ou deixando de agir) sob efeito da repressão. Se nos detivermos apenas na teoria, perdemos a oportunidade de captar a complexidade do processo.

A necessidade de auscultar dialeticamente os sentimentos docentes e observar suas práticas em experiências reais serve para descartarmos qualquer possibilidade de enquadrarmos os sujeitos e suas histórias em gavetas teóricas e personalidades revolucionárias ideais, bem como nos proporciona desvelar processos, apreender como eles 
se manifestam na vida real dos sujeitos, compreender suas contradições como partícipes das suas próprias experiências coletivas a oscilar entre a solidariedade, a reprodução e a competição. Com efeito, os teóricos, por vezes, idealizam a classe operária como sendo portadora do espírito revolucionário, e é possível que se idealize, também o professor e a categoria docente, por sua realidade objetiva do trabalho intelectual, como portador de uma razão social impecável, iluminados por ciências e saberes, bem como do espírito crítico da resistência. Devemos considerar, todavia, a hipótese de que por vezes os professores reproduzam a ideologia dominante, já que são sujeitos e estão repletos de contradições e humanidade. Entre os sentimentos de impotência frente à repressão do Estado e frustrações diante da própria categoria, ao considerarem suas participações como negativas e algo traumáticas nas greves, os professores descortinaram suas experiências reais e suas fraturas e ainda, evocaram a união da categoria como objeto central da discussão, evidenciando que a sua ausência aponta para sua premência. Há um esforço, ainda que no discurso, de coletividade.

Além disso, nas margens da organização social docente é preciso considerar todo o cenário. Nossa pesquisa se debruçou no descortinar o cenário de precarização do trabalho docente nos seus pressupostos intencionais do ponto de vista institucional, nas suas manifestações legais e nos desdobramentos diretos e indiretos do trabalho na escola, além de suas consequências mais dramáticas, como o quadro de adoecimento. A intensificação da exploração do trabalho, a proletarização que força o sujeito a atuar como objeto é um processo agressivo e está em curso na SEE-SP, e sabemos que onde há exploração, provavelmente encontraremos vestígios e indícios de resistências, sejam individuais, no absenteísmo, na negativa em preencher mais e mais papeis, seja no âmbito coletivo, no fazer-se de greves, ainda que fraturadas, incompletas.

Mas também erraremos se dimensionarmos, para mais, a responsabilidade individual docente pelo seu aparente imobilismo quando não aderirem às greves. Exigimos uma consciência social e um sacrifício (já que os movimentos coletivos demandam tais elementos), mas se não costurarmos essas fendas ao cenário que desvelamos estaremos cometendo um deslize epistemológico tanto por impor uma idealização sobre sujeitos (daí a frustração de não encontrarmos tantos militantes assíduos entre os docentes) quanto por desprezar o sacrifício original dos professores que já lutam (apenas) no exercício diário do trabalho precário.

Como brechas para olhar os sujeitos por meio da luta, para além da ação coletiva, é preciso compreender também o cotidiano docente como palco de batalhas e frustrações. Não necessariamente tomados dos conceitos de resistência, mas de um olhar peculiar de cotidiano, que como afirmou Heller, pode estar prenhe de elementos que aprofundam as distâncias entre expectativas e realidade, de idealismos e acepções anteriores que não se realizam. Heller sugere que "as esperanças estão impregnadas de contingência, mas o que experimentamos são os difíceis fatos da vida, a limitação factual de nossas possibilidades. A discrepância entre esperança e experiência é motivo de constante insatisfação e descontentamento" (HELLER \& FEHER, 1998: 35)

Consideramos que os professores entram em movimentos de greve porque, apesar de muitos não concordarem com esta estratégia, ela é uma herança atual e legítima dos 
movimentos docentes, que floresceram com o novo sindicalismo, ou como os professores afirmam, o único recurso que produz algum efeito, mesmo que seja apenas visibilidade. Sobre isso, assim como já mencionado no depoimento da professora Marisa em sua memória de greves, 57 docentes ativos sugeriram que elas são, ainda, o único instrumento que os docentes têm em mãos para se fazerem ouvidos e vistos pela sociedade e pelo governo, mesmo que alguns deles não concordem com esta estratégia ou façam ressalva que seus efeitos serão diretamente proporcionais à união dos professores.

Quando questionados sobre os instrumentos de resistências que existem e sobre possíveis alternativas futuras, os professores, em maioria, retomaram a importância da greve, talvez por não encontrar, no plano das experiências reais, outras estratégias de negociação. Assim se manifestou a docente que, mesmo discordando, afirmou que "não deveria ser através da greve, mas infelizmente não estamos enxergando outro jeito" (Questionário 2). Os relatos apontam a falta de alternativas, assim, nesta mesma direção, outra docente salientou que a greve é o único recurso de pressão contra o governo, ainda asseverou: "não vejo outra maneira!" (Questionário 70).

A visibilidade do movimento aparece como o diferencial que faz com que muitos docentes, ainda que discordem destas estratégias e conclamem mais união da categoria, citem a greve como único caminho atual de resistência e negociação, como a docente que afirmou que "se não houver uma manifestação, o governo acredita que os professores estão satisfeitos. Com as paralisações e manifestações, o governo acaba tendo que tomar uma postura" (Questionário 87). Outra professora lembrou que "apesar do governo não atender as reivindicações, ainda é uma forma de mostrar a nossa insatisfação, os nossos desejos e opiniões" (Questionário 113). Há uma crítica, sempre presente, aos modos como as greves são conduzidas, mas foram muitos os docentes que ressaltaram a escassez de alternativas ou modelos de resistência. A professora do questionário 119 afirmou que a greve é melhor instrumento para reivindicar as demandas dos trabalhadores docentes mas criticou o movimento recente e ressaltou:

Mesmo não sendo do sindicato, me predispus a buscar materiais e distribuir nas escolas, vizinhança, espaço de lazer que frequentava. No entanto, o "povo" do sindicato não me recebeu bem e nem fizeram questão de me passar os materiais que solicitei. Apesar de, no momento, eu não estar na greve. Se os sindicatos não têm conseguido negociar, é preciso que o governo veja a nossa insatisfação e se não for através de ações no coletivo ele não se incomoda. Os professores devem utilizar as mobilizações em massa (Questionário 119).

Em uma perspectiva do discurso, superando as questões trazidas pela memória e experiências reais, vividas pelos sujeitos, a greve como estratégia ideal parece se regenerar aos olhos dos professores. Como apresentamos, muitos deles admitiram que esse tipo de movimento é o único caminho existente para pressionar o Estado, único aporte de negociações de demandas. Claro que esse retorno também pode ter se dado em função da confrontação que o questionário colocou aos docentes, pois após rememorarem suas experiências de greve e destilarem suas decepções, os professores foram instados a pensar e 
sugerir formas alternativas de superar esse modelo de resistência (Questão 8.5 do Questionário). Muitos, portanto, retornaram a ele.

Mas ainda que em menor número, vale destacar que mais de vinte docentes sugeriram possíveis alternativas de resistências para superar as greves, considerada, por muitos, formas obsoletas de negociação. Podemos considerar que tais sugestões se direcionam em dois grupos e, embora diminutos, entendemos ser importante discuti-los.

O primeiro, citado por pelo menos 12 professores, reside na seara política de representatividade, no voto, com escolhas de governantes comprometidos com a educação, como a professora destacou:

Não vejo outra forma para nossa reivindicação, uma vez que há muito tempo não conseguimos eleger representantes de nossa causa. Embora acredite que a desvalorização da classe atinge o país em todas as redes. Seria necessária uma mobilização nacional. Como somos formadores de opinião, a melhor forma é a conscientização dos alunos, para que desta forma, futuramente, escolham melhor nossos representantes (Questionário 112).

Nessa vertente, uma docente advertiu que a estratégia alternativa à greve seria "não votar no PSDB" (Questionário 64), e um professor depôs que a greve seria o melhor instrumento, "mas o pouco engajamento e a fraca mobilização inviabilizam o movimento. Se a categoria conseguisse eleger políticos comprometidos com a categoria poderia ter maior poder de pressão" (Questionário 65). Notamos alguns limites nesta seara, na contradição entre a negação partidária e o apelo da representatividade política nas instâncias de poder público.

No bojo das críticas ao sindicato e às condutas de greve se encontram os argumentos de que os sujeitos envolvidos são partidários, de que agem sob a lógica da política partidária. Isso sugere uma ética antipartidarista ou, como preferem os próprios docentes consultados, apartidária. Mas como utilizar a representação política para defender os direitos e demandas do professorado, sem vincular-se a partidos? Rosário Lugli, ao estudar os percursos trilhados pelos docentes no campo político, em um movimento corroborado pela categoria na ânsia de representatividade, apontou que o processo passa necessariamente por este limite. A autora descreveu a trajetória histórica desse movimento iniciado nos anos 1930 e destacou uma marca das campanhas políticas dos docentes nos anos que se seguiram:

Como característica comum a absolutamente todos os anúncios, temos a omissão dos partidos políticos, que se vincula à intenção de permanecer "politicamente neutros", expressa nos estatutos redigidos quando da criação das entidades analisadas. Ora, tal "neutralidade" política, ante atuações que necessariamente implicavam posicionamento quanto a políticas de estado no campo educacional, revela-se, na prática, impossível, e termina por se realizar apenas como um distanciamento de legendas partidárias, visto como um meio de afastar os "políticos profissionais" das decisões educativas, numa tentativa 
de delimitar o espaço do campo profissional tornando-o âmbito exclusivo das decisões técnicas dos educadores (LUGLI, 2005: 234).

A invocação de representatividade política não é novidade entre os professores e as suas associações, tampouco o ethos antipartidário da categoria. É nesse limite que Lugli localiza um círculo vicioso que perdura quase um século, entre o discurso da representatividade e a crítica do partidarismo, desvelando algumas experiências malsucedidas, do ponto de vista político, como expressões da ineficiência desta estratégia 16. Estas considerações, no entanto, não servem aqui para resolver um imbróglio histórico na categoria, nem para deslegitimar as opiniões dos professores consultados em nossa pesquisa. Nosso entendimento é a compreensão de que, se por um lado, os docentes não se sentem satisfeitos com seus aportes de negociação e, por outro, continuam a patinar na elaboração de novos aportes.

O segundo grupo de sugestões registradas pelos professores, como propostas de ações de resistência e negociação, é a articulação (e ação) direta, por meio de mídias e redes sociais. Ao menos 10 deles as citaram como formas de renovar as práticas de resistência, como a professora ao afirmar que "as greves acabam com o sistema nervoso e emocional", preconizando, então, substitui-las por "diálogos e cartas, aliás, hoje é com e-mails, torpedos, whats app, e outros, para os nossos dirigentes, e publicando" (Questionário 89). Como ela, outra docente advertiu que "os professores deveriam utilizar instrumentos que falem diretamente com o povo, como as redes sociais" (Questionário 113).

Aí reside uma certa novidade, impulsionada principalmente a partir dos protestos populares ocorridos em junho de 2013 em várias partes do país, iniciados com demandas locais, localizadas no "Movimento Passe Livre" (contra o aumento de passagens de ônibus em São Paulo), mas que ganharam heterogeneidade, força, visibilidade e volume durante pelo menos dois meses seguintes ${ }^{17}$. A novidade estaria no recurso de articulação. Os movimentos e protestos emergentes naquela conjuntura se engendraram por meio das redes e mídias sociais. De acordo com Peruzzo, os instrumentos revelaram um ineditismo do modus operanti nos movimentos de junho de 2013:

\footnotetext{
16 No referido artigo, Rosário Lugli utilizou-se das categorias teóricas de campus e habitus, de Pierre Bourdieu, para evidenciar os limites da atuação representativa dos professores no campo político, e para isso discutiu algumas das experiências eleitorais e políticas, entre elas, em São Paulo, as trajetórias de Sólon Borges dos Reis, ex-presidente do CPP, com sucessivos mandatos de deputado estadual e federal. O populismo e a inserção dos professores aos jogos do campo político balizaram tais experiências, pois o próprio Sólon Borges, que foi tão aclamado pela categoria e tão bem votado, chegou a ser vice-prefeito e secretário de Paulo Maluf, um político reconhecidamente avesso às demandas do professorado paulista.

${ }^{17}$ Ao discutir os protestos de junho de 2013 para compreender a dimensão das tecnologias midiáticas em sua articulação, Cicília Peruzzo buscou caracterizá-los da seguinte forma: "Não se trata somente de um movimento de esquerda, muito menos só dos setores tradicionais de representação política. Até o repúdio a partidos políticos de esquerda roubaram a cena em alguns momentos nas manifestações de junho e julho. No conjunto, houve uma mescla de segmentos de classe e de tendências político-ideológicas: de esquerda, liberais, conservadores, grupos com conotação, gente que quer mudar o Brasil, gente que apenas aderiu e participou, mas sem saber bem o porquê ou, como lembra Chauí (2013), o fez apenas para sair de casa. Enfim, os protestos de junho de 2013 - momento em que tiveram maior adesão - expressaram o heterogêneo" (PERUZZO, 2013, 79).
} 
O uso da internet, das mídias e redes sociais virtuais e de celulares se constitui num diferencial importantíssimo do novo grande movimento social que mexeu com o País e com as visões sobre ele. As mídias e redes sociais virtuais (YouTube, Flickr, Facebook, Instagram, Twitter etc.) se constituem em canais de informação, em ambientes comunicacionais, em pontos de encontro, enfim, em redes e, às vezes, até em comunidades, que facilitaram os relacionamentos (entre os que estão conectados), a articulação entre as pessoas e as ações conjugadas (acertos de dia, local e hora para encontros presenciais). Claro que servem ainda de arena de debate, de difusão, acesso e troca de informação. Tudo isso, no que se refere ao ambiente interno no ciberespaço e no que diz respeito ao processo de mobilização que acaba por desembocar nas ruas das principais cidades do País (PERUZZO, 2013: 79).

Mas, no mesmo texto, ela aponta os limites na compreensão do alcance dos recursos mencionados quando se trata de movimento social. Para ela, a dimensão da novidade reside nos meios de comunicação da articulação do movimento social, mas este somente se materializa e se realiza, enquanto tal, nas ruas, que são espaços tradicionais dos protestos populares. Assim, a autora continua:

As mídias e redes virtuais são importantes canais e ambientes comunicacionais para a articulação, mas a tecnologia somente favorece as mobilizações se o seu uso for atrelado à luta social mais ampla, ou seja, relacionadas às organizações de base popular, comunidades, movimentos sociais etc. - extra ciberespaço ou existentes nele - porém, portadores de vínculos consistentes e duradouros (PERUZZO, 2013: 83).

Nestas considerações, entendemos que as redes sociais não substituiriam, portanto, as greves e manifestações, conforme sugeriram alguns docentes. Elas quiçá aumentariam o seu potencial articulador. Mas a recente experiência de 2015 é exemplar para diminuir tais expectativas, pois houve uma greve que, apesar de longa, perpetuou problemas anteriormente apontados pelos professores no que tange à articulação e união da categoria, ainda que utilizando recursos de mídias e redes sociais.

Com isso, reiteramos que os contrapontos observados diante das propostas colocadas pelos docentes possuem o escopo de problematizar o olhar dos sujeitos acerca da superação do recurso das greves como meio principal de negociações no campo do trabalho e dos diretos docentes. Não porque a elegemos como melhor instrumento da luta, mas porque, na prática, nenhuma outra experiência se materializou para que possamos avaliar. Não se trata de negar a opinião docente, mas de confrontar a história e o cenário dado com a realidade que tem se construído no decurso das críticas, em um exercício de oposição ao idealismo (aqui no sentido hegeliano). Com efeito, ao compreender a insatisfação e o sentimento de que os movimentos grevistas tornaram-se, para os professores, saídas obsoletas, concluímos apenas que a categoria ainda não saiu do campo do discurso e da crítica. 
Cabe expor algumas das sugestões listadas pelos professores estaduais de Andradina para a renovação das formas de resistências dos docentes e que não se enquadram nos dois grupos anteriores. Enquanto 20 professores mencionaram os recursos, ainda que limitados, das redes sociais ou das eleições de representantes docentes no campo político, cerca de 40 propuseram "horizontes sem caminhos", metáfora do idealismo que apontamos. Ou seja, uma parte dos docentes revelou críticas e idealizações, mas em aportes vagos, tais como a professora que, ao questionar a greve, apontou: "Acho decadente ter que nos humilharmos tanto e nada adiantar. Deveria-se ter assegurados os direitos e demandas" (Questionário 21).

As estratégias de resistências docentes não implicam em subversão ou ruptura política. Alguns professores sugeriram 'greve branca' como melhor estratégia de negociação e consequente caminho para a (re)valorização da categoria ${ }^{18}$. Há posturas bastante conservadoras, inclusive. Um professor chegou a afirmar que os docentes deveriam deixar a profissão para tornar a categoria menor e, em função de uma relação entre "oferta e procura", os professores seriam valorizados, como parecem ter sido em um passado remoto, aqui bastante idealizado (Questionário 114). Outra, ainda destacou que a única solução seria evidenciar o bom trabalho realizado pelos professores na melhoria dos índices de avaliações institucionais e externas, de modo que assim o Estado passaria a respeitar a categoria (Questionário 126).

Para muitos docentes, a retomada da valorização do professor demanda 'conscientização', apesar do termo ser utilizado aqui de forma idealista. Devemos considerar que em suas demonstrações de insatisfação, os docentes apontam para um passado ideal, onde o professor era deveras respeitado, valorizado. Os professores reagem, muitas vezes, sob o olhar da tradição, isto é, de evocar um status anterior mesmo conservador, pois isso implica em questionar, nas entrelinhas, a própria expansão da oferta de ensino e sua democratização às classes populares, considerada um marco para o processo de precarização. Loureiro lembra que:

(...) a docência vive, por um lado, o mito de uma idade de ouro passada, onde detinha um prestígio e reconhecimento social inquestionável; por outro lado, vive o mito da construção de um novo futuro para a profissão, que se vem traduzindo numa crise de identidade profissional. Esta, por sua vez, caracterizase pela sua ambivalência, sendo favorável a novas reflexões e à revisão de tudo o que parecia estabelecido, mas é igualmente propícia ao retorno de diagnósticos mágicos ou fórmulas míticas de salvação em referência à tradição. Esta situação de crise (que só começa realmente a perpetuar-se quando já não há um modelo de substituição) conduziu à reflexão sobre a necessidade de transformar a docência numa "verdadeira profissão", que se baseia, por rum lado, na premissa de que esta aspiração permita o acesso a um estatuto social e ocupacional elevado e que, por outro lado, conduza a melhores escolas. (LOUREIRO, 2001: 11)

18 Greve branca consiste na paralisação sem afastamento dos trabalhadores do seu local de trabalho (MARRAS, 2001). Nos depoimentos que surgiram essa modalidade de estratégia, que foram três, os professores sugeriram não entregar notas bimestrais, por exemplo. 
No bojo do idealismo docente, às vezes vacilante, os reiterados termos 'consciência' e 'conscientização' surgem com recorrência, como na fala da professora ao indicar que "a única estratégia é a conscientização da sociedade, pais e alunos, em prol do professor, caso contrário, não consigo ver outra forma" (Questionário 58), ou "tentando conscientizar a sociedade em geral" (Questionário 65). Não fica claro, em grande parte dos depoimentos, o que realmente os professores estão a sugerir, tampouco o que compreendem pelo processo de "conscientizar", uma vez que, limitados ao plano do discurso, esta conscientização se apresenta como algo externo, e não interno, e sem caminhos, exemplos ou possibilidades práticas ou concretas. Há uma solução, mas não há ação, o que inviabiliza a prática.

\section{Resistência e precarização: considerações}

Impossível, nesse ponto, não lembrar das "ideias-força” de Paulo Freire, até porque inseridas no texto "Conscientização". Nelas, Freire provoca o leitor a compreender que as respostas que os homens precisam dar aos desafios que se colocam à sua realidade tanto transformam essa realidade quanto o próprio homem, desde que dialeticamente integradas ao plano da ação, da prática reflexiva dos sujeitos. Ironicamente (no nosso pensar), ele cita as greves como uma das possíveis respostas:

Cada relação de um homem com a realidade é, deste modo, um desafio ao qual deve responder de maneira original. Não há modelo típico de resposta, senão tantas respostas diferentes quantos são os desafios... E ainda é possível encontrar-se respostas bem diversas a um mesmo desafio. (...) Frente ao desafio que constitui para o operário alguma tentativa de utilização, que faz dele um objeto, pode responder pela passividade resignada, por um trabalho malfeito, pela greve, pela obediência ou rebeldia, uma organização sindical, um diálogo com os patrões etc. E, por outra parte, cada um destes tipos de respostas é susceptível de traduzir-se em múltiplas formas concretas. O importante é advertir que a resposta que o homem dá a um desafio não muda só a realidade com a qual se confronta: a resposta muda o próprio homem, cada vez um pouco mais, e sempre de modo diferente. (...) No ato mesmo de responder aos desafios que lhe apresenta seu contexto de vida, o homem se cria, se realiza como sujeito, porque esta resposta exige dele reflexão, crítica, invenção, eleição, decisão, organização, ação... todas essas coisas pelas quais se cria a pessoa e que fazem dela um ser não somente "adaptado" à realidade e aos outros, mas "integrado". (FREIRE, 1980: 30).

Os professores estaduais de Andradina provavelmente experimentaram, no decurso de suas histórias, reflexões e ações, experiências de classe, avanços e retrocessos que, obviamente, também os transformaram como sujeitos. As contradições aqui expostas resultam, em muito, desse processo tão dialético do pensar e agir, entre o individual e o coletivo, entre o conformar e o resistir, processos que hoje estão tão marcados pela premência do imediato, da eficiência e da obsolescência que o cenário e as estruturas impõem. O cenário imposto pelo atual estágio do capitalismo, ao provocar a incredulidade, 
obscurantismo e dificultar o olhar estrutural/coletivo/transformador constitui a crise, mas, também, constitui o desafio.

Isto significa dizer que a crise da mobilização da categoria docente é parte do escopo da precarização do trabalho, engendrado na premência neoliberal da gestão sobre o trabalho e a educação, materializadas na fragmentação, na soberania do indivíduo, no estímulo aos financiamentos (leia-se endividamentos) por parte dos professores, enfim, na constituição de obstáculos para a unidade combativa da categoria docente.

As questões referentes às formas de resistências e negociações possibilitam extrair, na pesquisa, uma infinidade de análises e o material construído é ainda promissor neste sentido, a ser futuramente esgotado. Como observamos, as memórias e os olhares docentes apontaram sentimentos de incredulidade, crise de representatividade, críticas, sugestões ideais, poucos caminhos, muitos horizontes, mas, na totalidade dos discursos e das memórias, o consenso se localiza na insatisfação. Há uma crise de coletividade, há uma dificuldade em realizar e integrar greves efetivas ou traçar novas formas de negociação, mas ninguém nega a premência da luta, evidência maior da precarização do trabalho docente.

\section{Referências Bibliográficas}

ABRAMO: O professor, a organização corporativa e a ação política. In: CATANI, D.B. et al. (Org.). Universidade, escola e formação de professor. São Paulo: Brasiliense, 1986.

ANTUNES, Ricardo. O que é sindicalismo. Campinas: Círculo do Livro, 1996.

BAUER, Carlos. A classe operária vai ao campus: esboço de história social, trabalho precário, resistência e ousadia na universidade brasileira contemporânea. São Paulo: Sundermann, 2010.

FERNANDES, Maria José da Silva. As recentes reformas educacionais paulistas na visão dos professores. In Educação em Revista, Belo Horizonte, v.26, n.03, p. 75-102, dez. 2010.

FERREIRA JR, Amarilio, BITTAR, Marisa. A ditadura militar e a proletarização dos professores. In Educação e Sociedade, Campinas, vol. 27, n. 97, p. 1159-1179, set./dez. 2006.

FREIRE, Paulo. Conscientização: teoria e prática da libertação: uma introdução ao pensamento de Paulo Freire. São Paulo: Cortez, 1980.

FREITAS, Luiz Carlos. Os reformadores empresariais da educação e a disputa pelo controle do processo pedagógico na escola. In Revista Educação e Sociedade, Campinas, v. 35, nº 129, p. 1085-1114. out.-dez., 2014.

FREITAS, Taís Viúdes. O cenário atual da divisão sexual do trabalho. São Paulo: SOF, 2007. 
FRIGOTTO, Gaudêncio. A Produtividade da Escola Improdutiva: um re (exame) das relações entre educação e estrutura econômico-social capitalista. São Paulo: Cortez, 1986.

GALVÃO, Andréia. A reconfiguração do movimento sindical no governo Lula. In Revista Outubro n.18. $1^{\circ}$ semestre 2009.

GOULART, Débora Cristina. Entre a Denúncia e a Renúncia: A APEOESP (Sindicato dos Professores do Ensino Oficial do Estado de São Paulo) Frente às Reformas na Educação Pública na Gestão Mário Covas (1995-1998). Dissertação (Mestrado em Sociologia) Departamento de Sociologia do Instituto de Filosofia e Ciências Humanas, Universidade Estadual de Campinas, UNICAMP, Campinas, 226 f. 2004.

HALBWACHS, Maurice. A Memória Coletiva. Trad. Laís Teles Benoir. São Paulo: Centauro, 2004.

HELLER, Agnes e FEHÉR, Ferenc. A condição política pós-moderna. Rio de Janeiro: Civilização Brasileira, 1998.

HIRO, Cássio Hideo Diniz. História e consciência de classe na educação brasileira: lutas e desafios políticos dos trabalhadores em educação de Minas Gerais (1979 - 1983). Dissertação (Mestrado em educação) - Universidade Nove de Julho - UNINOVE - São Paulo, 168 f. 2012.

HYPOLITO, Álvaro Moreira. Trabalho docente, classe social e relações de gênero. Campinas: Papirus, 1997.

KAPOR, Tatiana Silvério. Da criação a primeira greve do magistério: APEOESP na sua primeira fase (1945-1963). IN ANAIS DO IX SEMINÁRIO NACIONAL DE ESTUDOS E PESQUISAS "HISTÓRIA, SOCIEDADE E EDUCAÇÃO NO BRASIL", João Pessoa, Universidade Federal da Paraíba, 2012, pp. 1100-1113.

LENIN, V.I. Sobre as Greves. 1889. Transcrito em HTML In marxists.org. Link https://www.marxists.org/portugues/lenin/1899/mes/greves.htm. Acesso em março de 2015.

LUGLI, Rosario S. Genta Um estudo sobre o CPP (Centro do Professorado Paulista) e o movimento de organização dos professores (1964-1990). Dissertação (Mestrado apresentado à Faculdade Educação) São Paulo: FEUSP, 1997.

MANACORDA, Mario Alighiero. História da Educação: Da antiguidade aos nossos dias. $5^{\mathrm{a}}$ Ed. São Paulo: Editora Cortez, 1996.

MARX, Karl. Salário, Preço e Lucro. Trad. Leandro Konder. São Paulo: Abril Cultural, Col. "Os Economistas", 1982.

NOGUEIRA, A. J. F. M. Relações de trabalho no setor público. In: Anita Kon. (Org.). Indústria, Trabalho e Tecnologia: Subsídios à Política Pública. São Paulo: CAPES / EITT-PUCSP: 7-36, 2005. 
OLIVEIRA, Mariana Esteves de. Apontamentos para a pesquisa histórica sobre o trabalho docente. Espaço Plural (Marechal Cândido Rondon. Online), v. 17, p. 551-583, 2016.

PERALVA, Angelina Teixeira. E os movimentos de professores da rede pública? In Cadernos de Pesquisa. São Paulo, n. 64, p. 64-66, fev. 1988.

PEREIRA, Luiz. O Magistério Primário numa Sociedade de Classe. São Paulo: Livraria Pioneira Editora, 1969.

PERROT, Michelle. As mulheres ou os silêncios da história. Bauru: Edusc, 2005.

PERRUZZO, Cicilia M. Krohling. Movimentos Sociais, redes virtuais e mídia alternativa no junho em que "o gigante acordou"(?). In Matrizes, ano7 - No 2 p.73-93, jul/dez.2013.

SÁ, Nicanor Palhares. O aprofundamento das relações capitalistas no interior da escola. In Cadernos de Pesquisa, São Paulo, nº 57, p. 20-27, maio de 1986.

SILVA, Reni Gomes da. Educação: campo de luta. Um estudo sobre os congressos do Sindicato dos Professores do Ensino Oficial do Estado de São Paulo - APEOESP (1997-2006). Dissertação (Mestrado em Educação) - Pontifícia Universidade Católica de São Paulo, São Paulo, 2008.

SNYDERS, Georges. Escola, classe e luta de classes. Lisboa: Moraes Editora, 1977.

SOUZA, Maria Celeste Reis Fernandes de; FONSECA, Maria da Conceição Ferreira Reis. Mulheres, homens e matemática: uma leitura a partir dos dados do Indicador Nacional de Alfabetismo Funcional. In Educação e Pesquisa, São Paulo, v. 34, n. 3, p. 511-526, Dec. 2008.

THOMPSON, Edward Palmer. A formação da classe operária inglesa: a árvore da liberdade. Rio de Janeiro: Paz e Terra, 1987.

VICENTINI, Paula Perin. A profissão docente no Brasil do século XX: sindicalização e movimentos. In BASTOS, Maria Helena Câmara \& STHEFANOU, Maria (org.) Histórias e Memórias da Educação no Brasil - século XX. Petrópolis: Vozes, 2005, p. 336-346.

VICENTINI, Paula Perin; LUGLI, Rosário Genta. História da Profissão Docente no Brasil: representações em disputa. São Paulo: Cortez Editora, 2009. 